\title{
Trophic effects of fishing southern rock lobster Jasus edwardsii shown by combined fatty acid and stable isotope analyses
}

\author{
M. A. Guest ${ }^{1, *}$, S. D. Frusher ${ }^{1}$, P. D. Nichols ${ }^{2,3}$, C. R. Johnson ${ }^{4}$, K. E. Wheatley ${ }^{4}$ \\ ${ }^{1}$ Tasmanian Aquaculture and Fisheries Institute, Marine Research Laboratories, Nubeena Crescent, Taroona, Tasmania 7053, \\ Australia \\ ${ }^{2}$ CSIRO Marine and Atmospheric Research, Castray Esplanade, Hobart, Tasmania 7000, Australia \\ ${ }^{3}$ Antarctic and Climate Ecosystems, University of Tasmania, Private Bag 80, Hobart, Tasmania 7001, Australia \\ ${ }^{4}$ School of Zoology, University of Tasmania, Private Bag 5, Hobart, Tasmania 7001, Australia
}

\begin{abstract}
The southern rock lobster Jasus edwardsii is a commercial species that has benefited from the complete protection offered by no-take reserves, with higher abundances and larger animals recorded in reserves than in adjacent fished areas. What remains unclear is whether there is any change in the diet of lobsters in reserves, for example, as a result of increased intraspecific competition for food. We used combined chemical tracers to examine the diet of lobsters in fished and reserve areas in 2 bioregions in eastern Tasmania. $\delta^{15} \mathrm{~N}$ values of lobsters were richer in fished than in reserve areas, indicating that lobsters eat a greater proportion of food items from higher trophic levels in fished areas. Mixing models suggest that ascidians, sea urchins and the turbinid gastropod were all important food sources for lobsters, but the importance of these food items differed between bioregions. This spatial variability may suggest that the small size of the reserve in one bioregion is inadequate at ensuring the diet of lobsters is protected from fishing pressure. Fatty acid profiles of lobsters supported the importance of these food sources to lobsters. Differences between bioregions, or inside and outside of reserves, were not apparent using fatty acids. The present study highlights that lobster fishing has the capacity to alter the trophic status of prey for generalist predators and suggests that fatty acid analyses may be limited in detecting changes in the dietary composition of such generalist feeders.
\end{abstract}

KEY WORDS: Effects of fishing $\cdot$ Food webs $\cdot$ Marine protected areas $\cdot$ Stable isotopes $\cdot$ Fatty acids

\section{INTRODUCTION}

No-take marine protected areas, or reserves, are an increasingly common tool used to mitigate the effects of fishing and preserve biodiversity (Jennings 2000). In the absence of manipulative experiments and data that is collected prior to fishing activities, no-take marine reserves also provide a unique opportunity to test specific hypotheses about the effects of fishing on community structure and dynamics (Pinnegar et al. 2000). Typically, these hypotheses have focused on evaluating the direct effects of fishing, such as changes to the density of targeted species (e.g. Roberts \& Polunin
1991, Dahlgren \& Sobel 2000, Schroeter et al. 2001, Shears et al. 2006). Not surprisingly, the abundance and often mean size of fished species is generally found to increase in reserves compared with adjacent fished areas (Edgar \& Barrett 1997, Follesa et al. 2007, Sonnenholzner et al. 2009). More recently, however, the indirect effects of fishing on the trophic structure of reserve and fished communities have been considered with evidence of trophic cascades in several communities following the increase of predator densities in reserve areas (Scheffer et al. 2005, Kramer \& Heck 2007).

The southern rock lobster Jasus edwardii (Hutton) is one species demonstrated to benefit from the estab- 
lishment of marine reserves in which complete cessation of fishing is enforced (Edgar \& Barrett 1997, 1999, Shears et al. 2006). Increases in the abundance of $J$. edwardsii have been linked with trophic cascades in reserves that shifted from sea urchin- to algal-dominated reef habitats (Shears \& Babcock 2003). What remains unclear, however, is the potential dietary shift of lobsters due, in part, to greater lobster density after reserve establishment (e.g. via intraspecific competition) that may have unknown effects on other components of the reef community.

Chemical tracers such as stable isotope and fatty acid analyses are means by which the diet of lobsters in fished and reserve areas may be determined. As lobsters macerate their food upon ingestion, the chemical tracer approach has advantages over conventional methods of dietary analysis, such as gut content analysis where identification is often labour intensive, requires taxonomic expertise and soft bodied organisms may be overlooked (Sheppard \& Harwood 2005). Moreover, chemical tracers identify food that is assimilated over a period of time and is of nutritional importance, rather than that which is ingested at one point in time (Thomas \& Cahoon 1993). The basis of the chemical tracer approach is that consumers incorporate the marker, or signature, of their food source into their somatic and other tissues with minimal or predictable changes, thus providing an integrated record of the main food items in their diet (Peterson 1999, Dalsgaard \& St John 2004).

Stable isotope signatures refer to the variation in the ratio of rare heavy isotopes (e.g. ${ }^{13} \mathrm{C}_{1}{ }^{15} \mathrm{~N}$ ) to the more common lighter isotopes (e.g. ${ }^{12} \mathrm{C},{ }^{14} \mathrm{~N}$ ) in the target organism relative to an international standard (Peterson \& Fry 1987). As carbon changes very little between successive trophic levels (0 to $1 \%$, McCutchan et al. 2003), the carbon isotope can often indicate the ultimate source of primary production at the base of a consumer diet. The nitrogen isotope experiences greater fractionation per trophic level ( 3 to $4 \%$ ) and is thus used to infer the trophic status of a consumer (McCutchan et al. 2003). Signature fatty acids include individual fatty acids that are rare and unique ratios of commonly occurring fatty acids, both of which can be reflected in the fatty acid profile of a consumer (Dalsgaard et al. 2003). The combined use of stable isotope and fatty acid analyses therefore results in a greater capacity than that of a single technique to discriminate between potential food sources contributing to the diet of lobsters in fished and reserve areas.

The combined use of stable isotope and fatty acid analyses has been successfully applied to understanding the feeding ecology of marine invertebrates (Kharlamenko et al. 2001, Guest et al. 2008, Jaschinski et al. 2008, Soreide et al. 2008, Stevens et al. 2008), birds
(Karnovsky et al. 2008, Tierney et al. 2008) and mammals (Krahn et al. 2008, Tucker et al. 2008). No previous studies have examined the diet of lobsters, including wild Jasus edwardsii, using combined stable isotope and fatty acid analyses. More importantly, combined tracers have not previously been applied to understanding potential differences in the feeding ecology of a consumer between spatial management zones. The present study, on the east coast of Tasmania, uses a combined chemical tracer approach to determine if lobster diet differs between fished areas with low lobster density and reserve areas with higher lobster density. In doing so, it provides insight into both the feeding ecology of lobsters and its response to spatial management, and the efficacy of chemical tracers in resolving spatial differences in a consumer's diet.

\section{MATERIALS AND METHODS}

Study sites and species. The diet of Jasus edwardsii was studied in fished and reserve areas in 2 bioregions in eastern Tasmania, Australia (Fig. 1). The Maria Island reserve protects $\sim 7 \mathrm{~km}$ of coastline and was established principally to preserve marine habitats representative of the Tasmanian east coast, whilst the Governor Island reserve at Bicheno protects $\sim 1 \mathrm{~km}$ of coastline and was established to restore recreational fisheries species such as lobster back to unfished levels (Edgar \& Barrett 1999). Both regions are characterised by shallow algal reefs which support $J$. edwardsii and the blacklip abalone Haliotis rubra, the 2 most important fisheries species in Tasmania.

Each bioregion is represented by a single reserve with adjacent fished locations. Two locations (1 \& 2) were selected within each reserve, as well as 3 locations ( 3 to 5 ; see Fig. 1) in fished areas adjacent to each reserve, to maximise habitat similarity in terms of wave exposure and macroalgal communities between treatments. There were multiple sites within each location to ensure samples were representative of each location. Reserve and fished locations in each bioregion were similar to those used by Edgar \& Barrett (1997, 1999). Locations within each fished and reserve area were separated by at least $1 \mathrm{~km}$, and within each location, multiple sites were separated by approximately $100 \mathrm{~m}$.

At Maria Island, both total density and the density of large Jasus edwardsii were higher in reserves than adjacent fished areas (Edgar \& Barrett 1997, 1999, Barrett et al. 2009). There were no apparent differences in the density of $J$. edwardsii at Governor Island between reserve and fished areas (Edgar \& Barrett 1999, Barrett et al. 2009), but observations suggested that lobsters moved to deeper water and beyond surveying depth 


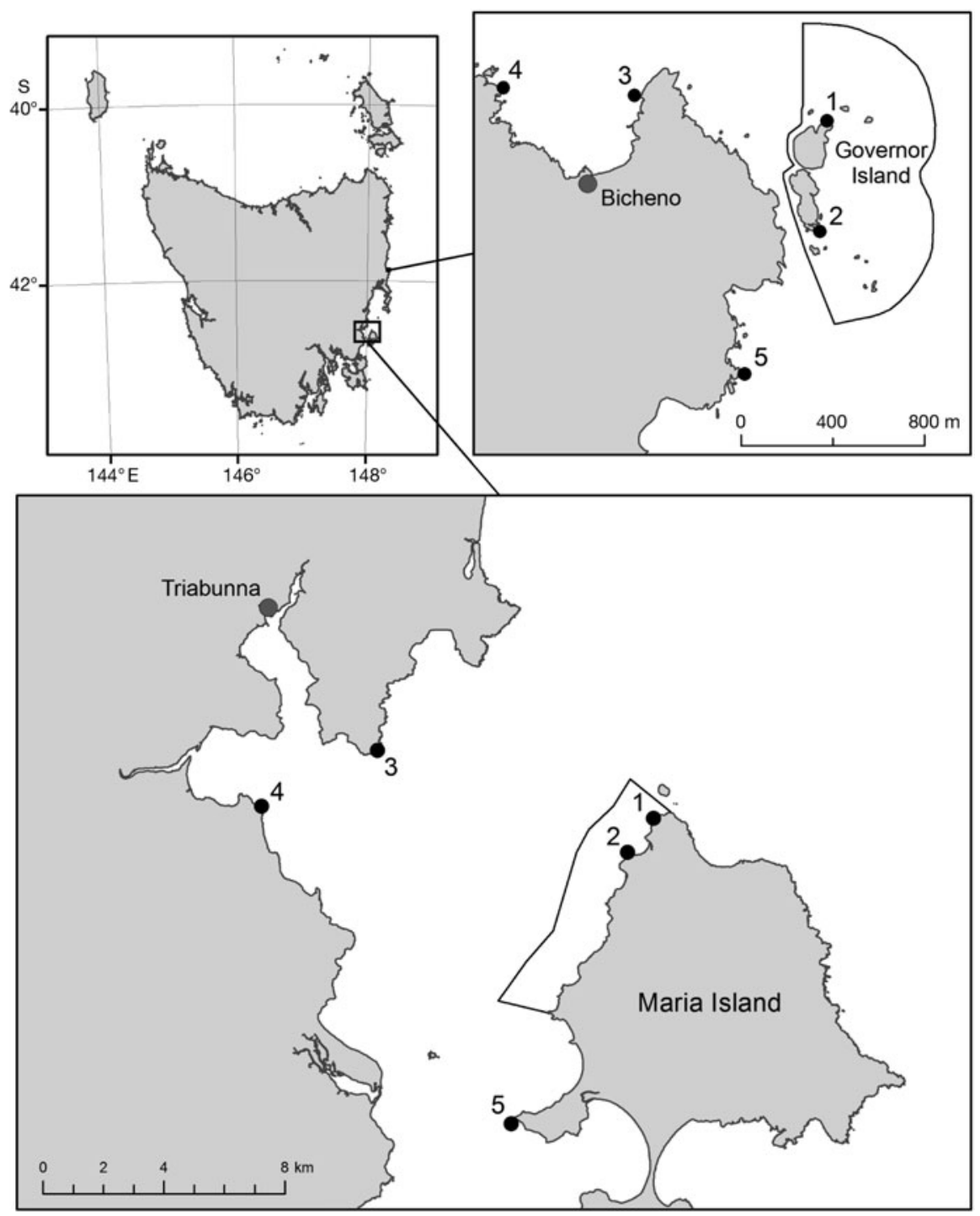

Fig. 1. Sampling locations (1 to 5) at Governor and Maria Islands, Tasmania. In each bioregion, Locations 1 and 2 are reserves (outlined) and 3 to 5 are fished

(5 m) in poor weather at this more exposed location (N. Barrett pers. comm.), making potentially higher densities of lobsters in reserves at Governor Island difficult to detect.

Potential lobster prey items included the blacklip abalone Haliotis rubra, the turbinid gastropod Turbo undulatus; the purple sea urchin Heliocidaris erythrogramma, the long-spined sea urchin Centrostephanus rodgersii, and the solitary ascidians Herdmania momus, Cnemidocarpa radicosa and Pyura gibbosa. The density of small abalone (H. rubra) was lower than large abalone in reserves than in fished areas (Edgar \& Barrett 1999). The densities of $H$. erythrogramma and C. rodgersii were greater in fished areas compared with reserve areas for both bioregions (Barrett et al. 2009). Densities of the turbinid gastropod T. undulatus were similar between fished and reserve areas at Governor Island, and strong recruitment at one location at Maria Island apparently caused the significantly higher abundance of $T$. undulatus recorded there (Buxton et al. 2006). No data are available on the density of ascidians. Red algal cover at $5 \mathrm{~m}$ depth was 11 to $24 \%$ at Maria Island and 10 to $20 \%$ at Governor Island. Dominant brown algal canopy species were Durvillea potatorum, Ecklonia radiata and Phyllospora comosa and their total cover was 40 to $80 \%$ at Maria Island and nearly $100 \%$ at Governor Island (Edgar \& Barrett 1999).

Sample collection and processing. A minimum of 3 samples of Jasus edwardsii and potential prey items were collected from each site within each location in reserve and fished areas for both stable isotope and fatty acid analyses. All samples were collected on 
SCUBA by hand. Due to the limited dive time, uneven numbers of samples among species and locations and between bioregions often resulted. Sampling of $J$. edwardsii occurred inside and outside of reserve areas and was non-destructive, involving the removal of the second or third walking leg in situ before release. Nelson et al. (2005) showed the fatty acid profiles of leg tissue to be similar to that of muscle tissue in both wild and cultured lobsters. Where possible, J. edwardsii from different size classes (small: $<80 \mathrm{~mm}$ carapace length [CL]; medium: $80-120 \mathrm{~mm} \mathrm{CL}$; large: $>120 \mathrm{~mm}$ CL) were collected to examine potential ontogenetic shifts in diet. Common red algae Plocamium angustum and brown algae (Ecklonia radiata, Phyllospora comosa) were collected at the same locations as the lobsters, and all samples were taken at 5 to $10 \mathrm{~m}$ depth.

All samples were frozen after collection $\left(-20^{\circ} \mathrm{C}\right)$, then thawed and rinsed in distilled water prior to processing. A leg muscle of lobster samples was removed from the exoskeleton, and a $2 \mathrm{~cm}^{3}$ section of muscle was removed from the abalone foot for later analysis. Muscular tissue of Turbo undulatus was also separated from the shell and other organs. Similarly, a portion of ascidian tissue, including the tunic, washed free of epiphytes, was also removed. Samples of sea urchin, comprising the lantern only, were rinsed, and small amounts of flesh removed for analysis. From each algal sample, tissue was selected haphazardly from the tip, midline and lower portion of each frond. All samples were then freeze-dried for 24 to $48 \mathrm{~h}$ and ground with a mortar and pestle. Samples were then partitioned for fatty acid and stable isotope analyses.

Stable isotope analysis. The ratios of ${ }^{13} \mathrm{C} /{ }^{12} \mathrm{C}$ and ${ }^{15} \mathrm{~N} /{ }^{14} \mathrm{~N}$ for all samples were calculated as the relative per mille $(\%)$ difference between the sample and the recognized international standard (Pee Dee belemnite carbonate for carbon; air for nitrogen) and analysed on a Micromass Isochrom continuous flow-isotope ratio mass spectrometer. Precision of the mass spectrometer calculated from duplicate samples was $0.2 \%$.

Fatty acid analysis. Dried animal and algal samples (15 mg of each) were trans-methylated to produce fatty acid methyl esters (FAME) using methanol-chloroform-conc. hydrochloric acid $\left(10: 1: 1,80^{\circ} \mathrm{C}, 2 \mathrm{~h}\right)$. Direct trans-methylation of samples has previously been validated against conventional methods (Christie 1982) for a microheterotroph (Lewis et al. 2000) and for striped trumpeter larvae and rotifers (M. P. Bransden \& G. A. Dunstan unpubl. data). FAME were extracted into hexane-chloroform $(4: 1,3 \times 1.5 \mathrm{ml})$. Analysis of gas chromatograms was performed with an Agilent Technologies $6890 \mathrm{~N}$ GC equipped with an HP-5 capillary column (50 $\mathrm{m} \times 0.32 \mathrm{~mm}$ internal diameter), a flame ionization detector (FID), a split/splitless injector and an Agilent Technologies 7683 auto sampler using gas chromatograph operating conditions previously described (Phillips et al. 2003a). Individual components were identified using mass spectral data (Finnigan Thermoquest GCQ GC-MS) and by comparing retention times with those of authentic laboratory standards.

Statistical analyses. Stable isotopes: A nested ANOVA tested for differences in carbon and nitrogen isotope values of lobster and potential food sources among fished and reserve locations (reserve effect: fixed, 2 levels). Location was a random factor and, where possible, nested within reserve effect, but was unbalanced as 2 locations were in reserve areas and 3 were in fished areas. Tests for differences between fished and reserve areas were done separately for each bioregion using the general linear models (GLM) procedure in SAS version 9.1.3 (SAS Institute), except for ascidians where there were too few data within either bioregion among reserve and fished areas to be analysed. The GLM procedure uses the method of least squares to fit GLMs, and is particularly suited to unbalanced data (Quinn \& Keough 2002). Data were checked for normality and homogeneity of variance by examination of residuals, and square root-transformed where necessary. Spearman rank correlation was used to determine if there was a relationship between lobster size and carbon and nitrogen isotope values.

Mixing model of Jasus edwardsii diet: Mixing models cannot provide a unique solution where there are more sources than elements, as in the present study. Instead, the IsoSource model (Phillips \& Gregg 2003) uses the average carbon and nitrogen isotope values of lobster and its potential prey items to calculate the upper and lower limits of the contribution that each food source makes to the diet of lobster. All possible combinations of each food source contribution (0 to $100 \%$ ) are examined in $1 \%$ increments. Combinations that sum to $0.5 \%$ of the lobster signature are considered feasible contributions. Results are reported as the distribution of feasible solutions for each food source as recommended by Phillips \& Gregg (2003). The 1st and 99th percentiles are also given rather than the full range, which is sensitive to small numbers of observations on the tails of the distribution (Melville \& Connolly 2003).

The average carbon and nitrogen isotope values of Jasus edwardsii and the potential prey items - abalone Haliotis rubra, the turbinid Turbo undulatus, the sea urchins Heliocidaris erythrogramma (Maria Island only) and Centrostephanus rodgersii (Governor Island only), ascidians, brown algae and the red alga Plocamium angustum-for reserve and fished areas within each bioregion were corrected for fractionation. Trophic fractionation for carbon is on average $0.5 \%$ per trophic level (McCutchan et al. 2003). For nitrogen, 
fractionation is larger and on average $3.5 \%$ per trophic level (McCutchan et al. 2003, Waddington \& MacArthur 2008). Fractionation rates can vary between species with such issues as diet type (Vanderklift \& Ponsard 2003) and dietary studies are required to confirm the fractionation rates of individual species (Pitt et al. 2009). As this was beyond the scope of the present study, the sensitivity of the IsoSource mixing model was run for each species using a range of fractionation rates for carbon and nitrogen. Changes in fractionation rates between 0.5 to $1.5 \%$ did not change the overall order of contributions made by most prey items to lobster diet (data not shown), thus the above standard levels of fractionation were used here. Lobsters were assumed to be 2.5 trophic levels above the base autotrophic source, ascidians 1.5 levels above base autotrophic source (Bingham \& Walters 1989) and the grazers, including abalone (Guest et al. 2008), turbinids and sea urchins, 1 trophic level above base autotrophic source. Isotope values for ascidians, sea urchins and brown algae were pooled within each respective phylum as, for the purposes of the model, there were insufficient differences between isotope values to discriminate individual species' contributions to lobster diet. For modelling of the reserve effect at Governor Island, stable isotope values of only one reserve and one fished location were available, and not all data were available for each species/phylum.

Fatty acid profiles: The diet of lobsters was compared between fished and reserve areas using principal component analysis (PCA) based on the fatty acid profiles of Jasus edwardsii and potential food sources. PCA reduces the number of dimensions produced by the large number of variables and uses linear correlations (components) to identify those fatty acids that contribute most to the separation between observed groups (Best et al. 2003). PCA was run on each species/phylum separately for fished and reserve areas in each bioregion to ensure that potential variability in fatty acid profiles of individual species/phylum due to environmental factors did not preclude subsequent trophic interpretation of data. For each species/phylum, a nested ANOVA on the scores of the first principal component (PC1, which described the majority of the variance between phyla) was then used to test for differences among bioregion (random, 2 levels), whether there was an effect of reserve (fixed, 2 levels) and for differences among location within reserve treatments (random, 5 levels) using the GLM procedure in SAS. PCA was then run on all species/phyla combined to examine the trophic relationships at fished and reserve areas in each bioregion. All analyses were performed on percent composition data, and fatty acids that contributed a mean of $>1.0 \%$ of total fatty acids to the fatty acid profile for each species/phy- lum were used in PCA. A $1 \%$ cutoff was chosen to minimise chromatographic overlap. Results were consistent with analysis of $\mathrm{mg} \mathrm{g}^{-1}$ fatty acid data (data not shown, but see Phillips et al. 2003b). The relationship between lobster size and principal component score, derived from fatty acids present in the profile of $J$. edwardsii, was examined using Spearman's rank correlation. All statistical analyses were performed using SAS version 9.1.3 (SAS Institute).

\section{RESULTS}

\section{Stable isotopes}

Carbon and nitrogen isotope values could be distinguished between broad phylogenetic groups (Fig. 2). For sea urchins, ascidian and brown algal species, the carbon and nitrogen values of similar species (e.g. Heliocidaris erythrogramma and Centrostephanus rodgersii) could not be distinguished and the isotopic values of these species were averaged for subsequent modelling of lobster diet (Fig. 3). As not all species were present in each bioregion, differences among bioregion in stable isotope values were not tested. Spearman's rank correlation showed no relationship between carbon $\left(\mathrm{r}_{\mathrm{S}}=0.06, \mathrm{p}=0.70, \mathrm{n}=46\right)$ or nitrogen isotope values $\left(\mathrm{r}_{\mathrm{S}}=0.16, \mathrm{p}=0.29\right)$ and size of Jasus edwardsii, so lobsters from all size classes were pooled for further analyses.

Nitrogen values of Jasus edwardsii were significantly more enriched at fished compared with reserve areas for both Maria (fished: $14.0 \pm 0.3 \%$; reserve: 13.0 $\pm 0.1 \%$ ) and Governor Islands (fished: $13.9 \pm 0.2 \%$; reserve: $13.4 \pm 0.1 \%$; Table 1 ). Nitrogen values of Plocamium angustum were also significantly more enriched at fished $(8.9 \pm 0.2 \%$ o $)$ compared with reserve areas $(6.0 \pm 0.1 \%$ o). Nitrogen values of Haliotis rubra differed significantly among locations, but not between fished and reserve areas. Carbon values of J. edwardsii, H. rubra, Heliocidaris erythrogramma, brown algae and $P$. angustum were significantly different among locations (Table 1). There were no significant differences in carbon or nitrogen isotope values between fished and reserve areas for any other species/phyla.

\section{Mixing model of Jasus edwardsii diet}

IsoSource modelling of $\delta^{13} \mathrm{C}$ and $\delta^{15} \mathrm{~N}$ values at Maria Island suggested a singular dominant potential contributor to the diet of lobsters at fished (ascidians, 80 to $93 \%$ ) and reserve areas (Turbo undulatus, 57 to $91 \%$ ), with all other food sources making much smaller con- 


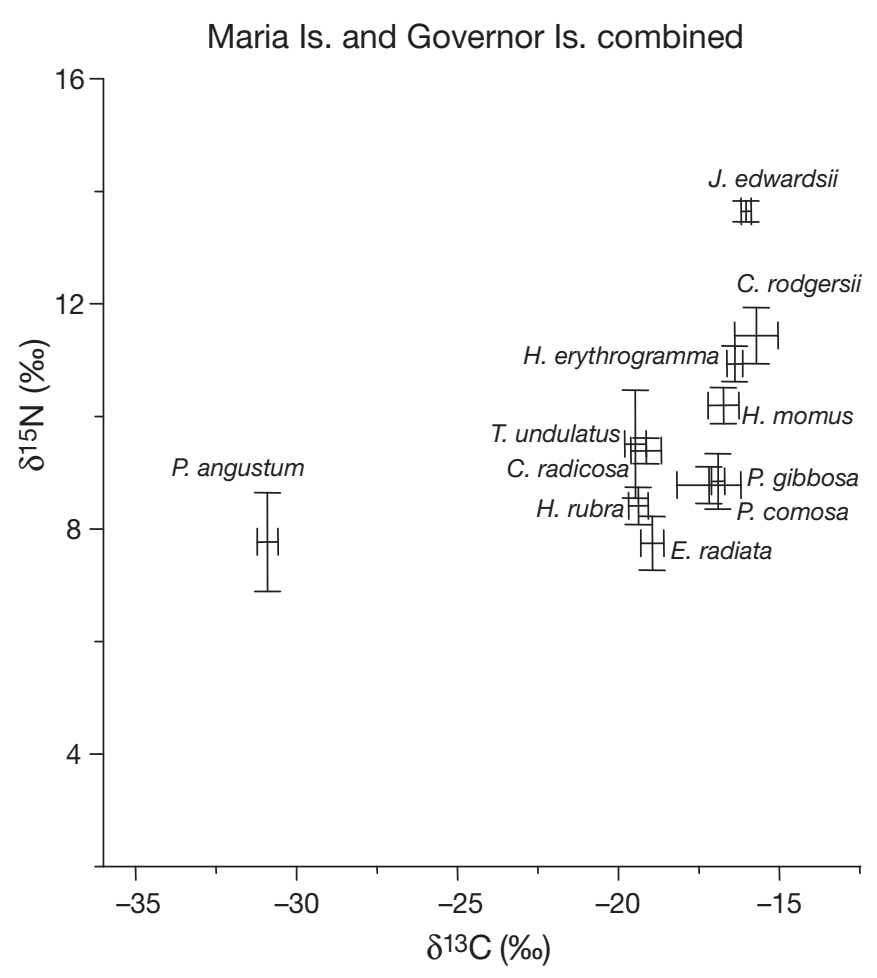

Fig. 2. Mean $( \pm \mathrm{SE})$ stable isotope values of $\delta^{15} \mathrm{~N}$ and $\delta^{13} \mathrm{C}$ for Jasus edwardsii and potential prey items by species (Haliotis rubra, Turbo undulatus, Heliocidaris erythrogramma, Centrostephanus rodgersii, Herdmania momus, Cnemidocarpa radicosa, Pyura gibbosa) pooled across bioregion and locations. Values for autotrophic sources (Plocamium angustum, Ecklonia radiata, Phyllospora comosa) are also included for comparison

tributions (Fig. 4). The pattern of likely food source contributions between fished and reserve areas was different for Governor Island. Sea urchins made substantial contributions to the diet of Jasus edwardsii in both fished and reserve areas but were the most dominant contributor in fished areas at Governor Island (58 to $71 \%$ ). Ascidians also made a strong likely contribution to lobster diet (24 to 53\%) in both fished and reserve areas but were most pronounced in reserve areas at Governor Island.

Sea urchins were the second most important potential contribution to lobster diet in fished areas at Maria Island, but, as previously mentioned, this contribution was much larger at Governor (58 to $71 \%$ ) than at Maria Island (0 to $13 \%$ ). Sea urchins were also an important potential contributor in the Maria Island reserve (4 to $22 \%$ ) but to a much lesser extent than at Governor Island. Haliotis rubra was the next most important potential food source for lobster in both fished ( 0 to $25 \%$ ) and reserve (0 to $32 \%$ ) areas at Governor Island, but made a relatively minor contribution to lobster diet in fished areas at Maria Island (0 to $8 \%$ ); the potential contribution of $H$. rubra in reserve areas at Maria Island (0 to 19\%) was similar to that at Governor Island. Turbo undulatus also made a minor contribution to lobster diet in fished areas at Maria Island ( 0 to $7 \%$ ) and in fished (0 to $16 \%$ ) and reserve areas (0 to $11 \%$ ) at Governor Island, and was the dominant contributor in reserve areas at Maria Island (57 to 91\%). Brown and red algae were consistently estimated to be unimportant contributors to the diet of lobsters in fished and reserve areas in both bioregions (Fig. 4).

\section{Fatty acid profiles}

Fatty acids $16: 0$ ( 7.3 to $55.9 \%$ of total fatty acids), 20:4n-6 (4.4 to $19.0 \%$ ) and $20: 5 n-3$ (3.4 to $13.3 \%$ ) commonly occurred in all species/phyla (Table S1 in online supplementary material, see www.int-res.com/articles/ suppl/m388p169_app.pdf). For Jasus edwardsii, 18:1n$9(15.7$ to $16.1 \%)$ was the most abundant fatty acid, with relatively high levels of 22:6n-3 (8.2 to $8.7 \%$ ), 18:0 (6.4 to $6.6 \%$ ) and $16: 1 \mathrm{n}-7$ (3.9 to $4.1 \%$ ). Haliotis rubra and Turbo undulatus were characterised by relatively high levels of 22:5n-3 (8.9 to $9.4 \%$ ) which was low or absent in all other phyla. In addition to 20:4n-6 and 20:5n-3, Heliocidaris erythrogramma and Centrostephanus rodgersii also had high levels of 20:1n$7,9,11(13.6$ to $19.7 \%)$ and $20: 3 n-6$ (11.7 to $15.1 \%)$. Ascidians had relatively high levels of 18:0 (4.0 to $8.8 \%$ ) and $22: 6 n-3(1.4$ to $8.3 \%)$. Fatty acids $14: 0$ (5.2 to $7.5 \%), 16: 1 \mathrm{n}-7$ (4.5 to $6.3 \%), 18: 1 \mathrm{n}-9$ (17.6 to $22.4 \%$ ) and $18: 4 \mathrm{n}-3$ (3.9 to $7.3 \%$ ) were common in both brown algal species. Fatty acids $14: 0$ (9.5 to $9.9 \%), 22: 0+$ hydroxy $(\mathrm{OH}) 20: 0$ (3.4 to $3.9 \%), 16: 1 \mathrm{n}-7$ (2.6 to $3.1 \%)$ and $20: 3 n-6(3.4$ to $3.6 \%)$ were the most abundant in the red alga Plocamium angustum. Percentages of fatty acids for all species/phyla were similar between fished and reserve areas (Table S1) and this pattern was consistent for absolute concentrations of fatty acids ( $\mathrm{mg} \mathrm{g}^{-1}$, not shown).

Spearman's rank correlation showed no relationship between lobster size and PC1 scores derived from the fatty acid profile of Jasus edwardsii $\left(\mathrm{r}_{\mathrm{S}}=\right.$ 0.16, $\mathrm{p}=0.13, \mathrm{n}=91$ ); therefore, lobsters from all size classes were pooled for all analyses although size classes are delineated in Fig. 5. All species/ phyla could be distinguished using PCA based on fatty acids contributing more than $1 \%$ of the lobster profile (Fig. 5), with the greatest overlap between Haliotis rubra and Turbo undulatus and some red and brown algae samples. PCAs that used a subset of fatty acids based on metabolic relationships or ratios of n-3/n-6 polyunsaturated fatty acids (PUFA) can sometimes yield additional information (e.g. Alonzo et al. 2005), but displayed no additional 

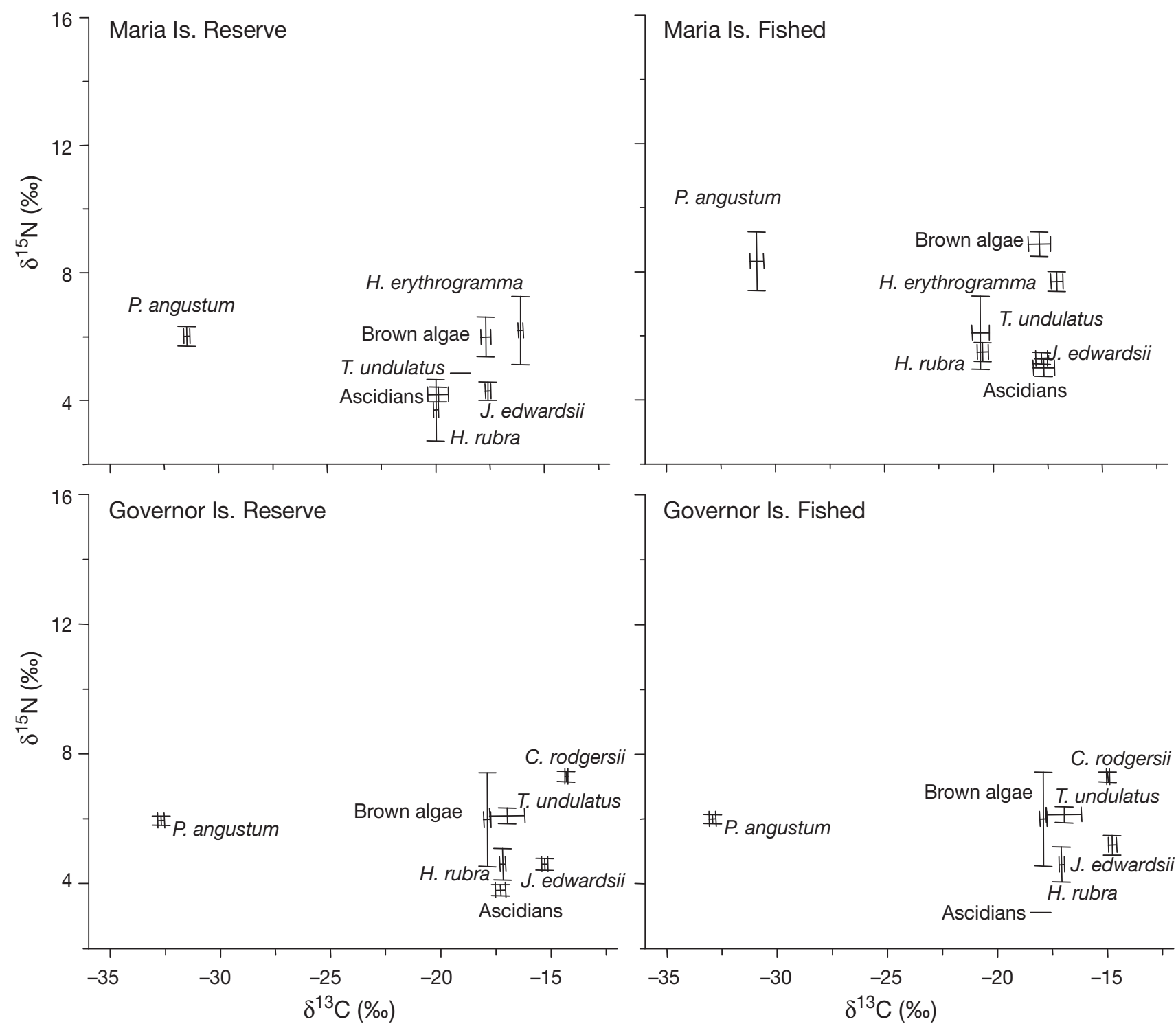

Fig. 3. Mean $( \pm \mathrm{SE})$ stable isotope values of $\delta^{15} \mathrm{~N}$ and $\delta^{13} \mathrm{C}$ for Jasus edwardsii and potential prey items corrected for fractionation (3.5\% for ${ }^{15} \mathrm{~N}$, and $0.5 \%$ for ${ }^{13} \mathrm{C}$ per trophic level). Species names are given in full in Fig. 2. J. edwardsii is assumed to be 2.5 levels above its autotrophic source; Haliotis rubra, Turbo undulatus, Heliocidaris erythrogramma and Centrostephanus rodgersii are assumed to be 1 level above; and the remaining ascidians are assumed to be 1.5 levels above their autotrophic source. These values were used in the IsoSource mixing model. Values are shown for reserve and fished treatments for each bioregion. Isotope values for Governor Island were unavailable for some species/phyla. For reserve areas, the red alga Plocamium angustum and the sea urchin C. rodgersii are from Governor Island fished locations; for one fished area, the turbinid T. undulatus and brown algae are from Governor Island reserve $(\mathrm{n}=1)$. For $T$. undulatus at Maria Island reserve areas and ascidians at Governor Island fished areas, SE are too small to be seen and are shown as a single horizontal line

dietary patterns in the present study (see Nelson et al. 2002). For all species/phyla combined, at both bioregions and at fished and reserve areas, 78.8 to $82.1 \%$ of the total variance was explained by PC1 (Fig. 5). Along PC1 at fished and reserve areas, $J$. edwardsii was always closest to $H$. rubra and $T$. undulatus. Sea urchins and red algae were always furthest from lobsters, and brown algae intermediate between these groups. The major contributing fatty acids to PC1 were similar for each bioregion and reserve treatment (Fig. 5). Of those fatty acids that can indicate dietary contribution, 20:4n-6 and 22:5n-3 were important in distinguishing among species/ phyla along PC1, and 20:3n-6, 20:2n-6, 22:6n-3 and 22:5n-3 were important in distinguishing among species/phyla on PC2.

PC2 explained 6.4 to $8.6 \%$ of the total variance among species/phyla observed for each bioregion, 
Table 1. Results of ANOVAs using $\delta^{13} \mathrm{C}$ and $\delta^{15} \mathrm{~N}$ values for each species/phylum. As there were insufficient replicates of all species/phyla at each bioregion and/or location, species/phyla and bioregion are analysed separately. Data are pooled across location for some species/phyla where there were insufficient data among locations for each treatment to permit analyses. Superscripts (M: Maria Island; G: Governor Island) denote the bioregion(s) analysed. Degrees of freedom are the same for $\delta^{13} \mathrm{C}$ and $\delta^{15} \mathrm{~N}$ and thus only reported once. $\delta^{15} \mathrm{~N}$ values for Jasus edwardsii, Haliotis rubra and Ecklonia radiata were square root-transformed

\begin{tabular}{|c|c|c|c|c|c|c|c|}
\hline \multirow{2}{*}{ Factor } & \multirow[t]{2}{*}{ df } & \multicolumn{3}{|c|}{$\delta^{13} \mathrm{C}$} & \multicolumn{3}{|c|}{$-\delta^{15} \mathrm{~N}$} \\
\hline & & MS & $F$ & $\mathrm{p}$ & MS & $F$ & $\mathrm{p}$ \\
\hline \multicolumn{8}{|l|}{ Jasus edwardsii } \\
\hline Reserve effect ${ }^{\mathrm{M}}$ & 1 & 0.517 & 0.13 & 0.740 & 0.178 & 49.49 & 0.006 \\
\hline Location(Reserve effect) & 3 & 3.921 & 4.74 & $<0.001$ & 0.004 & 0.12 & 0.947 \\
\hline Error & 41 & 0.827 & & & 0.296 & & \\
\hline Reserve effect ${ }^{\mathrm{G}}$ & 1 & 0.561 & 2.11 & 0.182 & 0.641 & 5.29 & 0.050 \\
\hline Error & 8 & 0.265 & & & 0.121 & & \\
\hline \multicolumn{8}{|l|}{ Haliotis rubra } \\
\hline Reserve effect ${ }^{\mathrm{M}}$ & 1 & 0.483 & 0.01 & 0.920 & 1.321 & 7.44 & 0.072 \\
\hline Location(Reserve effect) & 3 & 40.70 & 9.07 & $<0.0001$ & 0.178 & 5.02 & 0.004 \\
\hline Error & 50 & 4.487 & & & 0.035 & & \\
\hline Reserve effect ${ }^{\mathrm{G}}$ & 1 & 0.055 & 0.04 & 0.848 & 0.014 & 0.18 & 0.684 \\
\hline Error & 7 & 1.411 & & & 0.078 & & \\
\hline \multicolumn{8}{|l|}{ Ascidians } \\
\hline Species $^{\mathrm{M}, \mathrm{G}}$ & 1 & 0.133 & 0.05 & 0.824 & 7.847 & 1.41 & 0.244 \\
\hline Error & 31 & 2.663 & & & 5.575 & & \\
\hline Reserve effect ${ }^{\mathrm{M}, \mathrm{G}}$ & 1 & 8.857 & 3.72 & 0.062 & 3.637 & 0.64 & 0.431 \\
\hline Error & 31 & 2.382 & & & 5.711 & & \\
\hline \multicolumn{8}{|l|}{ Heliocidaris erythrogramma } \\
\hline Reserve effect ${ }^{\mathrm{M}}$ & 1 & 4.293 & 0.31 & 0.618 & 11.570 & 5.76 & 0.096 \\
\hline Location(Reserve effect) & 3 & 13.953 & 6.67 & 0.001 & 2.009 & 1.19 & 0.331 \\
\hline Error & 40 & 2.093 & & & 1.689 & & \\
\hline \multicolumn{8}{|l|}{ Brown algae } \\
\hline Species $^{\mathrm{M}}$ & 1 & 35.757 & 6.74 & 0.012 & 23.962 & 2.05 & 0.587 \\
\hline Error & 39 & 5.599 & & & 11.698 & & \\
\hline \multicolumn{8}{|l|}{ Ecklonia radiata } \\
\hline Reserve effect ${ }^{\mathrm{M}}$ & 1 & 0.082 & 0.01 & 0.920 & 1.231 & 9.33 & 0.055 \\
\hline Location(Reserve effect) & 3 & 6.919 & 0.89 & 0.458 & 0.132 & 0.83 & 4.984 \\
\hline Error & 28 & 7.759 & & & 0.159 & & \\
\hline \multicolumn{8}{|l|}{ Phyllospora comosa } \\
\hline Reserve effect ${ }^{\mathrm{M}}$ & 1.217 & 0.51 & 0.550 & 16.941 & 2.14 & 0.281 & \\
\hline Location(Reserve effect) & 2 & 2.397 & 1.16 & 0.342 & 7.915 & 0.29 & 0.751 \\
\hline Error & 14 & 2.069 & & & 27.122 & & \\
\hline \multicolumn{8}{|l|}{ Plocamium angustum } \\
\hline Reserve effect ${ }^{\mathrm{M}}$ & 1 & 18.328 & 0.32 & 0.631 & 36.791 & 34.31 & 0.028 \\
\hline Location(Reserve effect) & 2 & 57.929 & 3.68 & 0.048 & 1.072 & 3.32 & 0.062 \\
\hline Error & 16 & 15.750 & & & 0.323 & & \\
\hline
\end{tabular}

fished and reserve areas. Sea urchins and red algae were most remote from lobsters along PC2 and lobsters equidistant between ascidians and Haliotis rubra.

PCA of individual species showed that most of the total variance was explained by PC1 for all species (94 to $99 \%$, Table 2). For some species there was insufficient data to allow a comparison of fatty acid profiles between fished and reserve areas at each bioregion. For Herdmania momus and Pyura gibbosa, ANOVA showed significant differences PC1 scores of fatty acid profiles between species ( $p=0.001$, Table 2 ) and sub- sequent data for each species was pooled across bioregions to test for differences in fatty acid profiles between fished and reserve areas. Differences in the PC1 scores of fatty acid profiles between Heliocidaris erythrogramma and Centrostephanus rodgersii $(\mathrm{p}<$ 0.001 , Table 2) and insufficient numbers of each species at a single bioregion meant only a single region for these species was used to test for differences in fatty acid profiles between fished and reserve areas. For each species/phylum analysed separately, the ANOVA on PC1 scores of fatty acid profiles showed no signifi- 


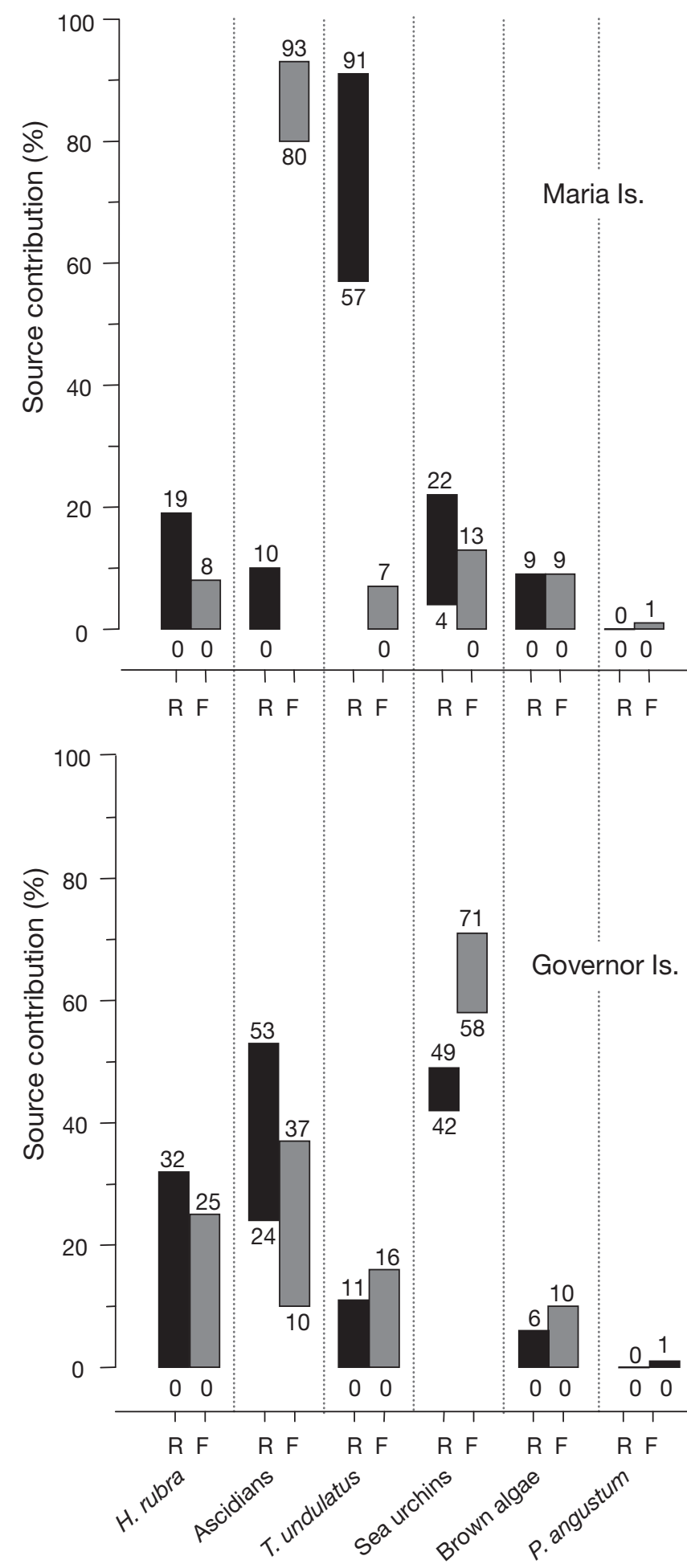

Fig. 4. Range of feasible contributions of the 6 potential food sources to the diet of the southern rock lobster Jasus edwardsii after correcting for both ${ }^{15} \mathrm{~N}$ and ${ }^{13} \mathrm{C}$ fractionation. Bars are the 1st and 99th percentiles for the distribution of feasible contributions. Species within phyla (i.e. ascidians, sea urchins and brown algae) are pooled where isotopic signatures between species were not sufficiently distinct to be used in the model. See Fig. 2 for full species names. R: reserve area; F: fished area cant differences between fished and reserve areas (Table 2). PC1 scores based on major fatty acids of Haliotis rubra $(\mathrm{p}=0.006)$, and $H$. erythrogramma $(\mathrm{p}=$ 0.039 ) showed significant differences among locations (Reserve effect $\times$ Bioregion), and brown algae showed significant differences among bioregion $(p=0.010)$.

\section{DISCUSSION}

More enriched $\delta^{15} \mathrm{~N}$ values for lobsters in fished areas than in reserve areas at Maria Island and, to a lesser extent, Governor Island, provide direct evidence that the diet of Jasus edwardsii differs between areas of low (fished areas) and high (reserve areas) lobster density. The results of the IsoSource mixing model for Maria Island supports this apparent shift in potential food sources with the model indicating lobsters eat a larger proportion of ascidians in fished areas than they do in adjacent reserves. Differences in $\delta^{15} \mathrm{~N}$ values of lobster could not be attributed to differences in the size of lobsters between fished and reserve areas. Turbo undulatus was identified as the dominant food source in reserve areas at Maria Island, and although the results of the mixing model for Governor Island support the importance of ascidians in the diet of lobsters, there was only a slightly greater contribution of ascidians to the diet of lobsters in reserves compared with fished areas. Sea urchins made a similar contribution to ascidians in reserves at Governor Island and were the dominant food source for lobsters in fished areas in this bioregion. Fatty acid profiles of lobsters and potential prey items also highlighted the potential contribution of ascidians but did not suggest any difference in the diet of lobsters in fished and reserve areas. As such, all subsequent comparisons of the diet of lobsters between reserve and fished areas refer to the IsoSource mixing model results. Fatty acid profiles indicating Haliotis rubra and $T$. undulatus are important prey of lobsters were consistent with the mixing model results.

\section{Lobster diet: reserve vs. fished areas}

More enriched values of $\delta^{15} \mathrm{~N}$ at fished areas compared with reserve areas suggest that lobsters in fished areas obtain a greater proportion of their diet from higher trophic levels, although such differences are not large. The ascidians Herdmania momus and Pyura haustor have previously been reported to consume invertebrate larvae (Bingham \& Walters 1989) and this is consistent with the higher trophic level assigned to ascidians (H. momus and Pyura gibbosa) compared with urchins, abalone and the turbinid in the present study. Note that zooplankton was observed to be a common 

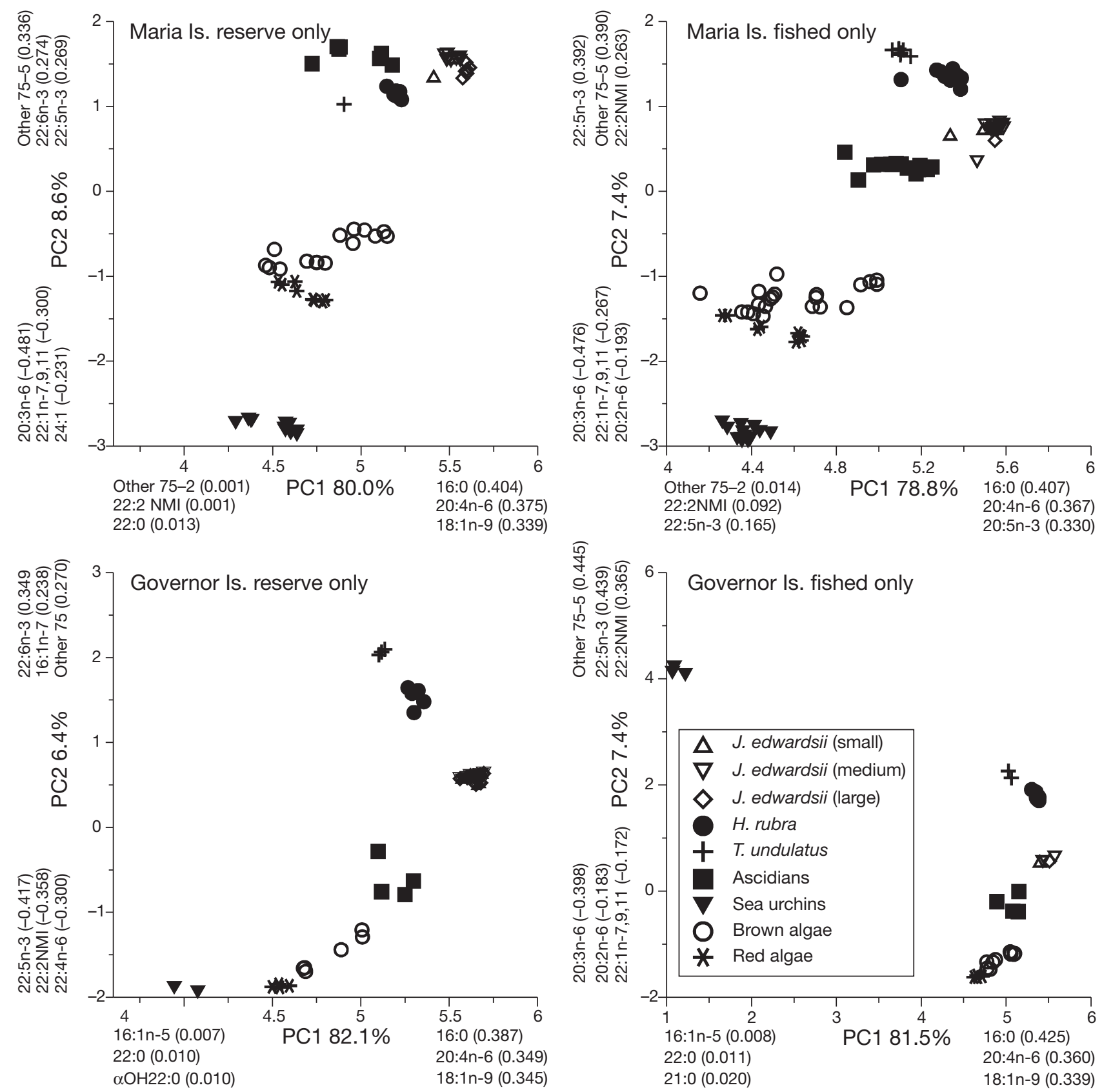

Fig. 5. Ordination of the first and second principal component (PC) scores, and corresponding loading weights (in parentheses) derived from the major fatty acids contributing $>1 \%$ to the profile of Jasus edwardsii and potential food sources (see Fig. 2 for full species names) for Maria and Governor Islands at fished and reserve locations. Percentage variance explained by each component is marked on each axis. Fatty acids listed along each axis are those that contribute most to the distribution of phyla within each region and treatment

component of the planktonic community at the time of Jasus edwardsii sampling, suggesting that, at least intermittently, ascidians have access to an invertebrate food source which contributes to their higher trophic status.

Ascidians have been reported as only a minor component in the diet of Panulirus interruptus (Castañeda-
Fernández-de-Lara et al. 2005) but a wide variety of consumers have been reported to eat ascidians (e.g. gastropods, chitons, sea stars: Kott 1997, Stotz et al. 2003; crabs: Bernárdez et al. 2000). The apparent predominance of ascidians in the diet of Jasus edwardsii in fished compared with reserve areas at Maria Island may be due to the reduced competition among lobsters 
Table 2. Results of ANOVAs of scores of the first principal component of the main fatty acids for each species/phylum. Data are pooled across bioregion for some species/ phyla where there were insufficient data for a reserve effect to be analysed. Superscripts (M: Maria Island; G: Governor Island) denote the bioregion(s) analysed. Degrees of freedom are the same for $\delta^{13} \mathrm{C}$ and $\delta^{15} \mathrm{~N}$ and thus only reported once. Significant differences among species meant that each species was then analysed separately to test for differences among reserve and fished treatments and location nested within each. PC1 scores of Heliocidariserythrogramma were square root-transformed

for this food source, and thus the potentially greater availability of ascidians in fished areas. Additionally, the ease with which lobster can capture ascidians may make them an attractive food source given their relatively high levels of omega-3 long-chain $\left(\geq \mathrm{C}_{20}\right)$ PUFA, particularly 22:6 (n-3), which are important for the functioning of the nervous system, adaptive processes and immunity to infections and parasitic diseases (Kolakowska et al. 2003). The absence of seasonality in the abundance of ascidians examined here may also make them an attractive food source to lobsters given their more continuous supply. Whilst there are no data on the potential difference in the density of ascidians between fished and reserve areas, Herdmania momus and Pyura gibbosa are common species on the east coast of Tasmania. It remains for future studies to examine the potential relationship between ascidian density, nutritional quality and lobster diet.

The slightly higher contribution of ascidians to lobster diet in reserve compared with fished areas at Governor Island, as suggested by the mixing model, contrasts with that recorded at Maria Island, and could be related to differences in the availability of ascidian prey between bioregions. Additionally, the small size of the reserve at Governor Island ( 1 km of coastline) may not be sufficient to ensure that the trophic structure in the reserve reflects that of unfished habitat in this bioregion. The role of reserve size in preserv-

\begin{tabular}{|c|c|c|c|c|c|}
\hline Factor & df & MS & $F$ & $\mathrm{p}$ & $\begin{array}{l}\text { PC1 } \\
\text { score }\end{array}$ \\
\hline Jasus edwardsii & & & & & 0.994 \\
\hline Reserve effect & 1 & 0.001 & 0.08 & 0.829 & \\
\hline Bioregion & 1 & 0.007 & 2.73 & 0.160 & \\
\hline Bioregion $\times$ Reserve effect & 1 & 0.001 & 0.51 & 0.508 & \\
\hline Location(Bioregion × Reserve effect) & 5 & 0.002 & 1.42 & 0.226 & \\
\hline Error & 82 & 0.002 & & & \\
\hline Haliotis rubra & & & & & 0.992 \\
\hline Reserve effect & 1 & 0.004 & 0.26 & 0.699 & \\
\hline Bioregion & 1 & 0.019 & 1.24 & 0.308 & \\
\hline Bioregion $\times$ Reserve effect & 1 & 0.017 & 1.13 & 0.330 & \\
\hline Location(Bioregion $\times$ Reserve effect) & 6 & 0.015 & 4.34 & 0.006 & \\
\hline Error & 99 & 0.003 & & & \\
\hline Turbo undulatus & & & & & 0.995 \\
\hline Reserve effect & 1 & 0.023 & 1.36 & 0.452 & \\
\hline Bioregion & 1 & 0.017 & 3.84 & 0.121 & \\
\hline Bioregion $\times$ Reserve effect & 1 & 0.017 & 3.70 & 0.127 & \\
\hline Location(Bioregion $\times$ Reserve effect) & 4 & 0.004 & 1.81 & 0.168 & \\
\hline Error & 19 & 0.002 & & & \\
\hline Ascidians & & & & & 0.961 \\
\hline Species & 2 & 0.688 & 16.62 & $<0.001$ & \\
\hline Error & 54 & 2.170 & & & \\
\hline Herdmania momus $^{\mathrm{M}, \mathrm{G}}$ & & & & & 0.987 \\
\hline Reserve effect & 1 & 0.010 & 0.05 & 0.822 & \\
\hline Error & 28 & 0.200 & & & \\
\hline Pyura gibbosa $\mathrm{a}, \mathrm{G}^{\mathrm{M}}$ & & & & & 0.965 \\
\hline Reserve effect & 1 & 0.065 & 2.01 & 0.187 & \\
\hline Error & 10 & 0.032 & & & \\
\hline Sea urchins ${ }^{\mathrm{M}, \mathrm{G}}$ & & & & & 0.992 \\
\hline Species & 1 & 0.200 & 11.33 & $<0.001$ & \\
\hline Error & 64 & 0.018 & & & \\
\hline Heliocidaris erythrogramma ${ }^{\mathrm{M}}$ & & & & & 0.993 \\
\hline Reserve effect & 1 & 0.001 & 0.86 & 0.412 & \\
\hline Location (Reserve effect) & 3 & 0.001 & 3.06 & 0.039 & \\
\hline Error & 40 & 0.0005 & & & \\
\hline Centrostephanus rodgersii $^{\mathrm{G}}$ & & & & & 0.995 \\
\hline Reserve effect & 1 & 0.006 & 7.62 & 0.110 & \\
\hline Location (Reserve effect) & 2 & 0.001 & 0.48 & 0.625 & \\
\hline Error & 16 & 0.001 & & & \\
\hline Brown algae & & & & & 0.992 \\
\hline Reserve effect & 1 & 0.021 & 1.21 & 0.470 & \\
\hline Bioregion & 1 & 0.093 & 13.50 & 0.010 & \\
\hline Bioregion $\times$ Reserve effect & 1 & 0.017 & 2.52 & 0.164 & \\
\hline Location (Reserve effect $\times$ Bioregion) & 6 & 0.007 & 1.13 & 0.353 & \\
\hline Species & 1 & 0.500 & 91.69 & 0.066 & \\
\hline Species $\times$ Reserve effect & 1 & 0.001 & 3.70 & 0.305 & \\
\hline Species $\times$ Bioregion & 1 & 0.005 & 0.67 & 0.447 & \\
\hline Species $\times$ Reserve effect $\times$ Bioregion & 1 & 0.0003 & 0.03 & 0.864 & \\
\hline $\begin{array}{l}\text { Species } \times \text { Location } \\
\text { (Reserve effect } \times \text { Bioregion) }\end{array}$ & 6 & 0.008 & 1.34 & 0.249 & \\
\hline Error & 81 & 0.006 & & & \\
\hline Plocamium angustum & & & & & 0.994 \\
\hline Bioregion & 1 & 0.013 & 0.611 & 0.439 & \\
\hline Error & 38 & 0.021 & & & \\
\hline Reserve effect & 1 & 0.040 & 1.59 & 0.297 & \\
\hline Location (Reserve effect) & 3 & 0.025 & 1.20 & 0.322 & \\
\hline Error & 35 & 0.721 & & & \\
\hline
\end{tabular}


ing habitat structure and trophic function in marine systems is poorly understood and beyond the scope of the present study, but is increasingly a topic of examination (e.g. Guest \& Connolly 2006, Martins et al. 2007). The greater similarity between the potential contributions of ascidians (and sea urchins) in fished and reserve areas at Governor Island indicates differences in the diet of lobsters may be attributed to differences among bioregion rather than a specific reserve effect.

Sea urchins were also identified as an important food source for lobsters at Governor Island, with a slightly greater contribution to lobster diet in reserves than adjacent fished areas. This is consistent with previous studies that also report sea urchins to be an important food source for lobsters (Homarus americanus: Carter \& Steele 1982; Jasus lalandii: Mayfield et al. 2001; J. edwardsii: Andrew \& MacDiarmid 1991, Pederson \& Johnson 2006). The predominance of lower order sea urchins in the diet of lobsters at Governor Island may account for depleted $\delta^{15} \mathrm{~N}$ values of lobsters in this bioregion.

At Maria Island, sea urchins contributed less to the diet of lobsters than at Governor Island, irrespective of treatment. The density of Heliocidaris erythrogramma is lower at Governor Island ( 10 ind. $200 \mathrm{~m}^{-2}$ ) than at Maria Island (>200 ind. $200 \mathrm{~m}^{-2}$, Barrett et al. 2009), most likely because the more exposed reef at Governor Island is less favourable to $H$. erythrogramma (Underwood et al. 1991, Edgar 2000). It is also possible that lower densities of sea urchins at Governor Island are due to the greater predation on sea urchins by lobsters in this bioregion. However, lower lobster density at Governor Island compared with Maria Island suggests that despite lower sea urchin density (Barrett et al. 2009), there may be sufficient sea urchins available to support lobsters in this bioregion.

Turbo undulatus was a major contributor to the diet of lobsters in reserves at Maria Island, but made minor contributions to the diet of lobsters in fished areas or at Governor Island, regardless of treatment. The density of $T$. undulatus did not differ inside and outside the reserve at Maria Island and thus cannot explain the larger contribution of $T$. undulatus to lobster diet in the Maria Island reserve. The shift by lobsters towards a more molluscan diet, however, indicates the potential influence of protection on lobster diet, and is likely a result of the increase in lobster density on the behaviour and/or density of alternate food sources such as ascidians, abalone and sea urchins. For example, Barrett et al. (2009) hypothesized that the apparent decline in abundance of small abalone in Maria Island reserves could be due to changes in juvenile abalone behaviour which delays the size at which abalone emerge in the presence of more and larger lobsters.
Changes in behaviour of potential prey such as abalone, and low or decreased abundance of preferred prey type such as ascidians and sea urchins, may explain the predominance of $T$. undulatus in the diet of lobster at Maria Island reserves. Further work is required to determine if $T$. undulatus also alter their size at emergence in the presence of more and larger lobsters to confirm the validity of this hypothesis. Differences in the contribution of $T$. undulatus between bioregions could be due to the regional availability of this species.

Haliotis rubra was not a major contributor to lobster diet but ostensibly made greater contributions at Governor Island than that at Maria Island. While anecdotal evidence suggests that abalone are a common prey item for Jasus edwardsii, there are no studies that demonstrate the relative contribution of abalone to lobster diet. Mayfield et al. (2001), however, indicated that consumption of abalone by J. lalandii declined where more preferred food such as mussels were available. In the present study, greater consumption of more preferred and/or easily available food such as ascidians may explain the relatively low contribution of abalone to lobster diet.

\section{Lobster diet: previous studies}

Previous characterisation of lobster diet using stable isotope or fatty acid analysis has generally been as a means to describe the nutritional requirements of postpueruli and juvenile Jasus edwardsii in aquaculture to maximize lobster growth rate and condition for commercial exploitation (James \& Tong 1997, Crear et al. 2002, Johnston et al. 2003, Ward et al. 2003, Nelson et al. 2004). To date, no other studies have used stable isotopes of either carbon or nitrogen to examine the diet of adult, wild $J$. edwardsii. The fatty acid profile of $J$. edwardsii from the present study is similar to those of wild lobsters used in a previous study to examine nutritional and taste differences between wild and cultured lobster (Nelson et al. 2005).

For some species of lobsters, ontogenetic shifts in diet have been recorded between early and late juvenile stages owing to the different social organisation of these life-history stages (Johnston 2003). We found no evidence of any difference in diet between the lobsters of different size classes $(<80,80-120$ and $>120$ mm CL) examined here. This is most likely due to the similarity in the size of the lobsters and the limitations of chemical tracer techniques in detecting minor shifts in the relative contributions of same-type food sources. For example, wholesale shifts in dietary choices associated with lobsters are usually between pueruli or postpueruli and juvenile stages, where diets shift from 
algal- to invertebrate-dominated (Jernakoff et al. 1993). All of the lobsters examined here were latejuvenile to adult stages, where changes in diet most likely comprise a change in the proportion of existing invertebrate food sources rather than a complete replacement of food types.

\section{Spatial variability in chemical tracers}

For some species, $\delta^{13} \mathrm{C}$ and/or $\delta^{15} \mathrm{~N}$ values were significantly different among locations within reserve/ fished areas or bioregion, however, the spatial variability of lobsters and other consumers did not track those of their potential food items among locations. Variability in $\delta^{13} \mathrm{C}$ values of the red alga Plocamium angustum may indicate a difference in carbon source or the rate of productivity of red algae at Location 5, which was more depleted in ${ }^{13} \mathrm{C}$ than other locations sampled. Small-scale spatial variability in $\delta^{13} \mathrm{C}$ values of the consumers Haliotis rubra and Heliocidaris erythrogramma could indicate minor shifts in dietary composition among locations, although for $H$. erythrogramma this is unlikely as shifts in $\delta^{13} \mathrm{C}$ values of consumers were not consistent with those of primary producers at the same locations. $P$. angustum and $H$. rubra also showed significant differences in $\delta^{15} \mathrm{~N}$ values among locations. For $P$. angustum, variation in $\delta^{15} \mathrm{~N}$ values may be due to differences in nitrogen source $\left(\mathrm{NO}_{2}\right.$ or $\mathrm{NH}_{4}{ }^{+}$, Peterson \& Fry 1987) among locations. For H. rubra, differences in $\delta^{13} \mathrm{C}$ and $\delta^{15} \mathrm{~N}$ values among locations were minor and negligible in terms of food web studies, but may suggest minor variation in the proportion of bacterial and macroalgal food sources to the diet of abalone among locations.

Fatty acid profiles exhibited less spatial variability than that of stable isotopes showing no differences among treatments, and only minor differences for a few species among bioregion (brown alga) or location (Haliotis rubra and Heliocidaris erythrogramma). This suggests that fatty acids are less sensitive to proportional changes in the diet of consumers than those of bulk signal stable isotopes and are best applied to resolve large differences in dietary contribution and separating the role of potential food sources that cannot be discriminated using stable isotopes (e.g. bacteria, Guest et al. 2008).

\section{Resolution of chemical tracers and lobster diet}

The present study demonstrates the capacity of stable isotope and fatty analyses as powerful tools in distinguishing between broad phylogenetic groups (e.g. lobster, abalone, sea urchins, brown and red algae,
Figs. 2 \& 5), and thus determining the relative contribution of those groups to a consumer's diet. The combined chemical tracer approach, however, is limited in distinguishing the contribution of individual species within phyla to the diet of lobsters. Despite being statistically different, the stable isotope and fatty acid values of various ascidian, sea urchin and brown algae species could not be distinguished within their respective phyla for the purposes of trophic analyses (also see Johns et al. 1979, Nelson et al. 2002), and so the dietary contribution of individual species within these phyla remains unclear.

As stable isotopes reveal a bulk signal of all biomolecules present in a sample, the lack of separation in isotopic signatures between species shown in this and other studies is partly explained by the taxonomic and functional similarity of food items (e.g. algae, grazers). $\delta^{13} \mathrm{C}$ is most strongly influenced by carbon source and the physiology of the target species (Farquhar et al. 1989, Raven et al. 2002), which may be similar in closely related taxonomic groups. $\delta^{15} \mathrm{~N}$ values are influenced by the trophic status of a consumer, and become difficult to detect for species of the same or overlapping trophic positions. For example, the isotopic separation of algal species, or the detection of a proportional change to lobster diet (in response to changes in lobster density) is difficult in situations where lobsters are consuming a wide range of food items from differing trophic levels. $\delta^{15} \mathrm{~N}$ values can also be influenced by diet quality (Vander Zanden \& Rasmussen 2001) and can vary between the tissue types of the target species (Pitt et al. 2009). Manipulative feeding trials were beyond the scope of the present study but may help to calibrate the feeding relationships indicated by stable isotopes in the present context.

By contrast, fatty acid analyses reveal the lipid fraction of a consumer diet, which can be labile and vary according to the physiology and nutritional condition of the target species (Ju \& Harvey 2004). In addition, the lipid content of the target species may influence the fatty acid profile of the tissues/species being examined (Ju \& Harvey 2004), with different fatty acids mobilised at varying rates both within and between species. This variation in lipid content and the mobilisation of individual fatty acids that occurs over different time periods to that of stable isotopes may explain potential differences in the signatures between the 2 techniques. Again, manipulative feeding trials are therefore required to calibrate the feeding relationships observed here.

Previous studies show that the lipid content of most species used in the present study are low in lipids (algae, Johns et al. 1979; abalone, Nelson et al. 2002; lobster, Nelson et al. 2005). For lobsters, lipids in muscular tissues such as walking legs are primarily stored 
as phospholipids, which are resilient to short-term changes in environmental and physiological factors (Cockcroft 1997), and are therefore considered useful for understanding longer term dietary changes (Corazze 1999).

Variation in the lipid content and the corresponding fatty acid profile among different tissue types within a single consumer can also indicate the diet of a consumer over different time periods. Here, the use of sea urchin lanterns for fatty acid analysis, compared to lipid-rich gonads thought to be consumed by lobsters, may explain the lower contribution of sea urchins to lobster diet indicated by fatty acid profiles compared with stable isotopes. It would be useful for future work to examine differences in fatty acid profiles of lanterns and gonads to verify the contribution of sea urchins to lobster diet using fatty acid analyses.

\section{CONCLUSIONS}

This is the first study to apply the use of combined chemical tracer techniques to examine the trophic effects of removing a significant predator from temperate reefs. The present study compared the chemical tracer profiles of lobsters in fished areas of low lobster density and reserve areas of high lobster density. Differences in $\delta^{15} \mathrm{~N}$ values of lobsters between fished and reserve areas indicated that lobsters eat a greater proportion of food items from higher trophic levels in fished areas than adjacent reserves. Differences in the stable isotope values between treatments, however, were not large and demonstrate the dietary plasticity of lobsters and the difficulty in evaluating potential trophic cascades in response to fishing pressure. Future application of chemical tracer techniques to detect changes in trophic structure and diet in response to fishing pressure may indicate more pronounced effects for dietary specialists. For generalist predators such as Jasus edwardsii, conclusions about fishing effects should be cautious, as it may be difficult to demonstrate potential trophic cascades until there are notable changes in the biota and functioning of reef systems. The present study also provides insight into the diet of wild $J$. edwardsii and is the first to recognise the role of ascidians and turbinid gastropods to lobster diet. Further work is required to identify the species of ascidians important to J. edwardsii.

Acknowledgements. We thank B. Connell, S. Fava, S. Ibbott, and R. Kilpatrick for assistance in the field. Thanks to G. Edgar and J. Valentine, who helped with identification of red algal species. The assistance of B. Mooney with laboratory processing and interpretation of fatty acid profiles was especially helpful. Thanks to N. Barrett and G. Edgar for use of data on sea urchin, turbinid and lobster density in fished and reserve areas. D. Holdsworth managed the CSIRO GC-MS facility. Thanks to 3 anonymous reviewers whose comments helped to improve the manuscript.

\section{LITERATURE CITED}

Alonzo F, Virtue P, Nicol S, Nichols PD (2005) Lipids as trophic markers in Antarctic krill. II. Lipid composition of the body and digestive gland of Euphausia superba in controlled conditions. Mar Ecol Prog Ser 296:65-79

Andrew NL, MacDiarmid AB (1991) Interrelations between sea urchins and spiny lobsters in northeastern New Zealand. Mar Ecol Prog Ser 70:211-222

Barrett NS, Edgar GJ, Buxton CD (2009) Changes in invertebrate and macroalgal populations within Tasmanian marine reserve in the decade following protection. J Exp Mar Biol Ecol 370:104-119

> Bernárdez C, Freire J, González-Gurriarán E (2000) Feeding of the spider crab Maja squinado in rocky subtidal areas of the Ria de Arousa (north-west Spain). J Mar Biol Assoc UK 80:95-102

Best NJ, Bradshaw CJA, Hindell MA, Nichols PD (2003) Vertical stratification of fatty acids in the blubber of southern elephant seals (Mirounga leonine): implications for diet analysis. Comp Biochem Physiol B 134:253-263

Bingham BL, Walters LJ (1989) Solitary ascidians as predators of invertebrate larvae: evidence from gut content analyses and plankton samples. J Exp Mar Biol Ecol 131:147-159

Buxton C, Barrett N, Haddon M, Gardner C, Edgar GJ (2006) Evaluating the effectiveness of marine protected areas as a fisheries management tool. Report No. FRDC 1999/162. Fisheries Research and Development Corporation, Deakin

Carter JA, Steele DH (1982) Stomach contents of immature lobsters (Homarus americanus) from Placentia Bay, Newfoundland. Can J Zool 60:337-347

Castañeda-Fernández-de-Lara V , Serviere-Zaragoza E, Hernández-Vázquez S, Butler MJ (2005) Feeding ecology of juvenile spiny lobster, Panulirus interruptus on the Pacific coast of Baja California Sur, Mexico. NZ J Mar Freshw Res 39:425-435

Christie WW (1982) Lipid analysis. Pergamon Press, Oxford

Cockcroft AC (1997) Biochemical composition as a growth predictor in male west-coast rock lobster (Jasus lalandii). Mar Freshw Res 48:845-856

Corazze G (1999) Lipid nutrition. In: Guillaume J, Metailler R, Kaushik S, Bergot P (eds) Nutrition and feeding of fish and crustaceans. Springer, London, p 111-130

> Crear B, Hart P, Thomas C, Barclay M (2002) Evaluation of commercial shrimp grow-out pellets as diets for juvenile southern rock lobster, Jasus edwardsii: influence on growth, survival, color, and biochemical composition. J Appl Aquacult 12:43-57

Dahlgren CP, Sobel J (2000) Designing a Dry Tortugas ecological reserve: How big is big enough? To do what? Bull Mar Sci 66:707-709

Dalsgaard J, St John M (2004) Fatty acid biomarkers: validation of food web and trophic markers using ${ }^{13} \mathrm{C}$-labelled fatty acids in juvenile sandeel (Ammodytes tobianus). Can J Fish Aquat Sci 61:1671-1680

Dalsgaard J, St John M, Kattner G, Müller-Navarra D, Hagen W (2003) Fatty acid trophic markers in the pelagic marine environment. Adv Mar Biol 46:225-340

Edgar GJ (2000) Australian marine life: the plants and animals of temperate waters. Reed New Holland, Chatswood Edgar GJ, Barrett NS (1997) Short term monitoring of biotic 
change in Tasmanian marine reserves. J Exp Mar Biol Ecol 213:261-279

Edgar GJ, Barrett NS (1999) Effect of the declaration of marine reserves on Tasmanian reef fishes, invertebrates and plants. J Exp Mar Biol Ecol 242:107-144

Farquhar GD, Ehlerlinger JR, Hubrick KT (1989) Carbon isotope discrimination and photosynthesis. Annu Rev Plant Physiol Plant Mol Biol 40:503-537

Follesa MC, Cuccu D, Cannas R, Sabatini A, Cau A (2007) Emigration and retention of Palinurus elephas (Fabricins, 1787) in a central western Mediterranean marine protected area. Sci Mar 71:279-285

Guest MA, Connolly RM (2006) Movement of carbon among estuarine habitats: the influence of saltmarsh patch size. Mar Ecol Prog Ser 310:15-24

Guest MA, Nichols PD, Frusher SD, Hirst AJ (2008) Evidence of abalone (Haliotis rubra) diet from combined fatty acid and stable isotope analyses. Mar Biol 153:579-588

James PJ, Tong LJ (1997) Differences in growth and moult frequency among post-pueruli of Jasus edwardsii fed fresh, aged or frozen mussels. Mar Freshw Res 48:931-934

Jaschinski S, Brepohl DC, Sommer U (2008) Carbon sources and trophic structure in an eelgrass Zostera marina bed, based on stable isotope and fatty acid analyses. Mar Ecol Prog Ser 358:103-114

Jennings S (2000) Patterns and prediction of population recovery in marine reserves. Rev Fish Biol Fish 10:209-231

Jernakoff P, Phillips BF, Fitzpatrick JJ (1993) The diet of postpuerulus western rock lobster, Panulirus cygnus George, at Seven Mile Beach, Western Australia. Aust J Mar Freshw Res 44:649-655

$>$ Johns RB, Nichols PD, Perry GJ (1979) Fatty acid composition of ten marine algae from Australian waters. Phytochemistry 18:799-802

Johnston DJ (2003) Ontogenetic changes in digestive enzyme activity of the spiny lobster, Jasus edwardsii (Decapoda; Palinuridae). Mar Biol 143:1071-1082

Johnston DJ, Calvert KA, Crear BJ, Carter CG (2003) Dietary carbohydrate/lipid ratios and nutritional condition in juvenile southern rock lobster, Jasus edwardsii. Aquaculture 220:667-682

Ju SJ, Harvey HR (2004) Lipids as markers of nutritional condition and diet in the Antarctic krill Euphausia superba and Euphausia crystallorophias during austral winter. Deep-Sea Res II 51:2199-2214

> Karnovsky NJ, Hobson KA, Iverson S, Hunt GL Jr (2008) Seasonal changes in diets of seabirds in the North Water Polynya: a multiple-indicator approach. Mar Ecol Prog Ser 357:291-299

Kharlamenko VI, Kiyashko SI, Imbs AB, Vyshkvartzev DI (2001) Identification of food sources of invertebrates from the seagrass Zostera marina community using carbon and sulphur stable isotope ratio and fatty acid analyses. Mar Ecol Prog Ser 220:103-117

Kolakowska A, Olley J, Dunstan GA (2003) Fish lipids. In: Zikorski ZE, Kolakowska A (eds) Chemical and functional properties of food lipids. CRC Press, Boca Raton, FL, p 221-264

Kott P (1997) Tunicates (Subphylum Tunicata). In: Shepherd SA, Davies M (eds) Marine invertebrates of southern Australia, part III. South Australian Research and Development Institute, Adelaide, p 1092-1255

Krahn MM, Pitman RL, Burrows DG, Herman DP, Pearce RW (2008) Use of chemical tracers to assess diet and persistent organic pollutants in Antarctic Type C killer whales. Mar Mamm Sci 24:643-663

Kramer LK, Heck KL Jr (2007) Top-down trophic shifts in
Florida Keys patch reef marine protected areas. Mar Ecol Prog Ser 349:111-123

Lewis T, Nichols PD, McMeekin TA (2000) Evaluation of extraction methods for recovery of fatty acids from lipidproducing microheterotrophs. J Microbiol Methods 43: $107-116$

- Martins GM, Hawkins SJ, Thompson RC, Jenkins SR (2007) Community structure and functioning in intertidal rock pools: effects of pool size and shore height at different successional stages. Mar Ecol Prog Ser 329: $43-55$

> Mayfield S, de Beer E, Branch GM (2001) Prey preference and the consumption of sea urchins and juvenile abalone by captive rock lobsters (Jasus lalandii). Mar Freshw Res 52: 773-780

> McCutchan JH, Lewis WM, Kendall C, McGrath CC (2003) Variation in trophic shift for stable isotope ratios of carbon, nitrogen, and sulfur. Oikos 102:378-390

Melville AJ, Connolly RM (2003) Spatial analysis of stable isotope data to determine primary sources of nutrition for fish. Oecologia 136:499-507

Nelson MM, Leighton DL, Phleger CF, Nichols PD (2002) Comparison of growth and lipid composition in the green abalone, Haliotis fulgens, provided specific macroalgal diets. Comp Biochem Physiol B 131:695-712

Nelson MM, Crear BJ, Nichols PD, Ritz DA (2004) Growth and lipid composition of phyllosomata of the southern rock lobster, Jasus edwardsii, fed enriched Artemia. Aquac Nutr 10:237-246

Nelson MM, Olley J, Crear BJ, Lewis T, Nichols PD (2005) Comparison of wild and cultured adult southern rock lobster, Jasus edwardsii: growth, sensory analysis and oil composition. Food Aust 57:499-509

> Pederson HG, Johnson CR (2006) Predation of the sea urchin Heliocidaris erythrogramma by rock lobsters (Jasus edwardsii) in no-take marine reserves. J Exp Mar Biol Ecol 336:120-134

Peterson BJ (1999) Stable isotopes as tracers of organic matter input and transfer in benthic food webs: a review. Acta Oecol 20:479-487

> Peterson BJ, Fry B (1987) Stable isotopes in ecosystem studies. Annu Rev Ecol Syst 18:293-320

Phillips DL, Gregg JW (2003) Source partitioning using stable isotopes: coping with too many sources. Oecologia 136: 261-269

Phillips KL, Jackson GD, Nichols PD (2003a) Temporal variations in the diet of the squid Moroteuthis ingens at Macquarie Island: stomach contents and fatty acid analyses. Mar Ecol Prog Ser 256:135-149

Phillips KL, Nichols PD, Jackson GD (2003b) Size-related dietary changes observed in the squid Moroteuthis ingens at Falkland Islands: stomach contents and fatty acid analyses. Polar Biol 26:474-485

> Pinnegar JK, Polunin NV, Francour P, Badalamenti F and others (2000) Trophic cascades in benthic marine ecosystems: lessons for fisheries and protected-area management. Environ Conserv 27:179-200

Pitt KA, Connolly RM, Meziane T (2009) Stable isotope and fatty acid studies in energy and nutrient studies of jellyfish: a review. Hydrobiologia 616:119-132

Quinn GP, Keough MJ (2002) Experimental design and data analysis for biologists. Cambridge University Press, Cambridge

- Raven JA, Johnston AM, Kubler JE, Korb R and others (2002) Mechanistic interpretation of carbon isotope discrimination by marine macroalgae and seagrasses. Funct Plant Biol 29:355-378 
Roberts CM, Polunin NVC (1991) Are marine reserves effective in management of reef fisheries? Rev Fish Biol Fish 1:65-91

Scheffer M, Carpenter S, de Young B (2005) Cascading effects of overfishing marine systems. Trends Ecol Evol 20: $579-581$

Schroeter SC, Reed DC, Kushner DJ, Estes JA, Ono DS (2001) The use of marine reserves in evaluating the diver fishery for the warty sea cucumber (Parastichopus parvimensis) in Califonia, USA. Can J Fish Aquat Sci 58:1773-1781

Shears NT, Babcock RC (2003) Continuing trophic cascade effects after 25 years of no-take marine protection. Mar Ecol Prog Ser 246:1-16

Shears NT, Grace RV, Usmar NR, Kerr V, Babcock RC (2006) Long-term trends in lobster populations in a partially protected vs. no-take marine park. Biol Conserv 132:222-231

Sheppard SK, Harwood JD (2005) Advances in molecular ecology: tracking trophic links through predator-prey food-webs. Funct Ecol 19:751-762

Sonnenholzner JI, Ladah LB, Lafferty KD (2009) Cascading effects of fishing on Galapagos rocky reef communities: reanalysis using corrected data. Mar Ecol Prog Ser 375: 209-218

Soreide JE, Falk-Petersen S, Hegseth EN, Hop H, Carroll ML, Hobson KA, Blachowiak-Samolyk K (2008) Seasonal feeding strategies of Calanus in the high-Arctic Svalbard region. Deep-Sea Res II 55:2225-2244

Stevens CJ, Limén H, Pond DW, Gélinas Y, Juniper SK (2008) Ontogenetic shifts in the trophic ecology of two alvinocaridid shrimp species at hydrothermal vents on the Mariana Arc, western Pacific Ocean. Mar Ecol Prog Ser 356: 225-237

Stotz WB, Gonzalez SA, Caillaux L, Aburto J (2003) Quanti-

Editorial responsibility: Yves Cherel,

Villers-en-Bois, France tative evaluation of the diet and feeding behaviour of the carnivorous gastropod, Concholepas concholepas (Braguiere, 1789) (Muricidae) in subtidal habitats in the southeastern Pacific upwelling system. J Shellfish Res 22: $147-164$

> Thomas CJ, Cahoon LB (1993) Stable isotope analyses differentiate between different trophic pathways supporting rocky-reef fishes. Mar Ecol Prog Ser 95:19-24

Tierney M, Nichols PD, Wheatley KE, Hindell MA (2008) Blood fatty acids indicate inter- and intra-annual variation in the diet of Adelie penguins: comparison with stomach content and stable isotope analysis. J Exp Mar Biol Ecol 367:65-74

Tucker S, Bowen WD, Iverson SJ (2008) Convergence of diet estimates derived from fatty acids and stable isotopes within individual grey seals. Mar Ecol Prog Ser 354:267-276

Underwood AJ, Kingsford MJ, Andrew NL (1991) Patterns in shallow subtidal marine assemblages along the coast of New South Wales. Aust J Ecol 6:231-249

Vander Zanden MJ, Rasmussen JB (2001) Variation in $\delta^{15} \mathrm{~N}$ and $\delta^{13} \mathrm{C}$ trophic fractionation: implications for aquatic food web studies. Limnol Oceanogr 46:2061-2066

> Vanderklift MA, Ponsard S (2003) Sources of variation in consumer-diet $\delta^{15} \mathrm{~N}$ enrichment: a meta-analysis. Oecologia 136:169-182

Waddington K, MacArthur L (2008) Diet quality and muscle tissue location influence consumer-diet discrimination in captive-reared rock lobsters (Panulirus cygnus). Mar Biol 154:569-576

Ward LR, Carter CG, Crear BJ, Smith DM (2003) Optimal dietary protein level for juvenile southern rock lobster, Jasus edwardsii, at two lipid levels. Aquaculture 217: 483-500

Submitted: May 6, 2008; Accepted: May 4, 2009

Proofs received from author(s): July 28, 2009 